\title{
HET SUBJECTIEVE KARAKTER VAN DE WAARDERING VAN DE GOODWILL EN DE BETEKENIS HIERVAN VOOR DE ACCOUNTANT
}

\author{
door D. van der Noord
}

\section{Goodwillbegrip.}

Voor de omlijning van de inhoud van het begrip goodwill is het noodzakelijk aansluiting te zoeken bij de doelstelling van de analyse. Deze doelstelling is economisch van aard en heeft in het bijzonder betrekking op een waarderingsprobleem. Zonder kennis van het doel van deze waardering zal het dus niet mogelijk zijn een doelmatige definitie van de goodwill te geven. Het doel van de waardering tenslotte is verbonden met het subject, voor wie het waardeoordeel van belang is. Dit subject kan niet de onderneming zijn, daar deze juist het object van de waardering is. Hieruit volgt, dat de inhoud van het begrip goodwill niet in verband moet worden gebracht met het immaterieel actief van de onderneming. Als zodanig zou het deel uitmaken van de collectiviteit van kapitaalgoederen, waarvan de waarde moet worden vastgesteld in relatie met de doeleinden van de bedrijfshuishouding ${ }^{1}$ ). Het gaat bij de waardering van de goodwill evenwel juist niet om deze doeleinden, maar om de doelstelling van de waarderende eigenaar(s), respectievelijk toekomstige eigenaar(s) van de onderneming. Deze beogen met de investering van vermogen een ondernemersinkomen te verwerven. Het karakteristieke hierbij is de onzekerheid ten aanzien van de grootte van dit inkomen. Het waarderend subject verdisconteert deze onzekerheid in zijn rentabiliteitseis ${ }^{2}$ ). Bij zijn overwegingen zal de ondernemer o.a. rekening houden met de eventueel bekende gemiddelde rentabiliteit in de betreffende branche over een zekere periode. Naarmate de uitersten van de rentabiliteit in de bedrijfstak verder uit elkaar verwijderd liggen, $z a l$ in de regel de gemiddelde rentabiliteit hoger zijn dan het gemiddelde van de minimum en maximum rentabiliteit ${ }^{3}$ ). Verder zal een voorzichtig type van ondernemer een grotere rentabiliteit verlangen dan een meer risico-minded georiënteerde investeerder.

Indien bij de ondernemende investeerder in het specifieke geval de verwachting bestaat, dat de toekomstige opbrengst van het vermogen groter zal zijn, dan de door hem geëiste rentabiliteit, is er voor hem sprake van een extra voordeel. Naarmate de verwachting minder stellig wordt in verband met de toekomstige onzekerheden voor de bedrijfstak in het algemeen en voor de onderneming in het bijzonder, zal de rentabiliteitseis worden verhoogd en zal het extra voordeel in betekenis dalen. Voorts zal i.h.a. de rentabiliteitseis worden verhoogd bij een toenemende grootte van het vreemde vermogen t.o.v. het eigen vermogen 3 ). In dit geval zijn buiten het bedrijf belegde reserves van belang. $Z_{i j}$ verminderen het risico voor de ondernemende investeerder en oefenen een druk uit op de stijging van de rentabiliteitseis.

1) Zie o.a. Prof. Dr J. L. Mey in het Mab. November 1954.

Prof. Dr O. Bakker is van mening, dat de goodwill wel behoort tot het ondernemingsactief (Leerboek Bedrijfshuishoudkunde deel II). Deze opvatting is echter niet bruikbaar ter verklaring van het goodwillverschijnsel, zoals dit zich voordoet bij de gehele of gedeeltelijke overdracht van ondernemingen.

2) Prof. Dr B. Pruyt in de "Naamloze Vennootschap" van Juli/Augustus 1953 - "Is Goodwill een zaak?" - legt op dit subjectieve karakter van de goodwill de nadruk.

3) Prof. Dr B. Pruyt in de "Naamloze Vennootschap" van September 1952 "Grenzen voor de risico-overdracht bij de financiering van de onderneming" - .

m a b blz. 116 
Onder goodwill kan men nu verstaan de subjectieve ondernemersverwachting van een extra rentabiliteit.

In het geval, dat geen noemenswaardige investering van vermogen plaats vindt, doch vrijwel uitsluitend tegen een onzeker inkomen arbeid wordt verricht, is deze definitie eveneens toepasselijk. De extra rentabiliteit bestaat hier in het verschil tussen de verwachte opbrengst van arbeid en de geëiste beloning. Bij onvervangbare arbeid (beroemd chirurg, groot kunstenaar) vallen deze beide grootheden als economische categorieën samen. De waarde van deze arbeid wordt bepaald door de opbrengstwaarde. Bij vervangbare arbeid zal wel sprake kunnen zijn van goodwill, daar de specifieke functie, waarin de arbeid voorziet, in dit geval door meerdere personen kan worden waargenomen. De waarde van de arbeid als grondslag voor de geëiste beloning wordt hier bepaald door de subjectieve schatting van de vervangingswaarde, welke in dit geval niet gelijk behoeft te zijn aan de verwachte opbrengstwaarde. Naarmate de arbeid minder gequalificeerd wordt, verkrijgt het goodwillverschijnsel een grotere betekenis. Ditzelfde geldt ook, indien het risico van de aanwending der arbeid geringer wordt. Dit doet zich onder meer voor bij een meer frequent contact met de cliëntèle of afnemers in vergelijking met een minder vaste verhouding.

Veelal wordt bij het bedrijfseconomisch definiëren van het begrip good. will verband gelegd met de oorzaken van de gunstige rentabiliteit. De bedoeling hiervan is het begrip te objectiveren. Moge dit voor de jurist belangrijk zijn, voor de bedrijfseconoom is deze poging gevaarlijk, daar zij hem op een verkeerd spoor kan brengen met betrekking tot de waardering van de goodwill. Het gevaar bestaat namelijk, dat geen voldoende rekening wordt gehouden met de onzekerheid van het ondernemen. De gunstige rentabiliteit wordt dan geheel toegeschreven aan enige bepaalde oorzaken, zonder dat men zich realiseert, dat nog andere invloeden werkzaam kunnen zijn. Niet alle rentabiliteitsbronnen zijn als zodanig te onderkennen. Ook wordt dikwijls onder de extra rentabiliteit verstaan het verschil tussen de verwachte ondernemerswinst en de gemiddelde rentabiliteit van de betreffende bedrij fstak of tussen de verwachte ondernemerswinst en de algemene rentestand. Ook hier is sprake van een objectivering in verband met de berekeningswijze, welke men van plan is te gaan volgen. In het onderstaande zal worden getracht aan te tonen, dat ook deze berekeningswijze in wezen subjectief is. Sommige auteurs denken bij de begripsbepaling in het bijzonder aan de goodwill als een objectieve prijs. Voor deze definities van de goodwill verwijs ik naar het speciale goodwillnummer van de "Naamloze Vennootschap" van Juli/Augustus 1942.

In „Een kwart eeuw V.A.G.A." legt Drs J. Vogel in een artikel over de goodwill de nadruk op de goodwill als waarschijnlijkheid. Hiermede wordt dus ook het subjectieve element op de voorgrond gesteld.

De aan deze waarschijnlijkheid ten grondslag liggende kansberekening kan immers niets anders zijn dan een individuele schatting. Ook bij de kostprijscalculatie komen deze schattingen voor, bijv. in het bijzonder bij de afschrijving der duurzame productiemiddelen. Het principiële verschil is evenwel, dat de kostprijscalculatie gericht wordt op het voorzienbare en meetbare, terwijl de goodwill.,berekening" juist betrekking heeft op het onvoorzienbare en onmeetbare. Waren alle risico's voorzienbaar en meetbaar, dan zou bij vrije concurrentie het winstverschijnsel verdwijnen en daarmede de goodwill. Ogenschijnlijk lijkt dit niet zo te zijn. In de bedrijfstak toch komen verschillende kostprijzen voor tengevolge van verschillen in grootte, structuur, productietechniek e.a. van de afzonderlijke onderne- 
mingen. Nochtans zijn ook verschillende kostprijzen een gevolg van de onvoorzienbaarheid. $Z_{\mathrm{ij}}$ ontstaan door een meer of minder juiste anticipatie op de toekomstige onzekerheden.

Tot besluit van deze inleiding wordt nog opgemerkt, dat in deze beschouwing onder winst steeds wordt verstaan de winst na aftrek van eventueel verschuldigde vennootschapsbelasting. Bij de waardering van een eenmanszaak of vennootschap onder firma blijft daarentegen de inkomstenbebelasting in principe buiten beschouwing, daar volgens het in ons land geldende belastingrecht de verkoper van de goodwill inkomstenbelasting betaalt, terwijl de koper op de goodwill fiscaal mag afschrijven. Ware dit niet het geval, dan zou de toekomstige winst met de te betalen inkomstenbelasting moeten worden verlaagd. Hieruit volgt, dat bij de waardering van de goodwill in incourante aandelen in beginsel met de inkomstenbelasting wel rekening zou moeten worden gehouden.

\section{Waardering van de goodwill.}

In het bekende werk over goodwill van Dicksee en Tillyard (4e ed. 1920) behandelt de laatste schrijver de juridische aspecten van het goodwillprobleem. In aansluiting hierop wordt door Dicksee de waardering uiteen gezet. Hierbij wordt sterk de nadruk gelegd op de omstandigheden, waaronder de waardebepaling kan optreden. Onder deze omstandigheden verstaat Dicksee dan de mate, waarin voldaan wordt aan de algemene voorwaarden - het recht van voortzetting op dezelfde plaats, het recht van gebruik op de oude naam, het recht zich als de opvolger te kunnen aandienen, het volledige beheer over de boeken, klantenlijsten enz., geen concurrentie door de oude eigenaar binnen redelijke afstand en tijd -, terwijl voorts ook van belang zijn de bijzondere voorwaarden, waaronder de overdracht plaats vindt, zoals overdracht van een geheel of van een deel. vrijwillige overdracht of overdracht tengevolge van de dood van de oorspronkelijke eigenaar, overdracht aan een nieuwe partner of aan de reeds aanwezige vennoot, enz. In het algemeen vormen deze punten volgens Dicksee misschien wel de belangrijkste factoren bij de waardebepaling. Steeds moet men nagaan of en in welke mate de terugtrekkende eigenaar de opvolger zal kunnen steunen of tegenwerken. Deze overdrachtssituaties spelen ook bij de moderne juridisch georiënteerde publicaties uiteraard een grote rol (zie o.a. "De goodwill in het privaatrecht en het belastingrecht" - Praeadviezen ter behandeling in de Algemene Vergadering van de Broederschap der candidaat-notarissen op 12 Juni 1953, en .,Goodwill als vermogensbestanddeel" door Prof. Mr W. C. L. van der Grinten in Maandschrift Economie April 1953).

Naast de overdrachtsfiguur kan ook de wijze van uitbetaling van de goodwill invloed uitoefenen op het goodwillbedrag, zoals nader is aangetoond door R. A. Dijker in de "Naamloze Vennootschap" van Mei 1947 - .De uitkering van goodwill van een uittredende vennoot".

Bij de bepaling van de goodwillwaarde in een fiscale situatie, waarbij dus de doelstelling is een waarde te vinden als uitvloeisel van de fiscale wetgeving, zijn van groot belang de fiscale richtlijnen (zie de reeds genoemde prae-adviezen).

Tenslotte kunnen tal van bijzondere omstandigheden het goodwillbedrag beïnvloeden, zoals het belang, dat gelegen kan zijn in de uitkoop van een concurrent, persoonlijke omstandigheden van de koper en verkoper, enz.

In het onderstaande zal van al deze invloeden worden geabstraheerd. Het uitgangspunt is de waardering van de goodwill bij een ,,willing seller

m a b blz. 118 
and buyer", welke over de overdracht van de onderneming onderhandelen. Bij deze waardering wordt voorts aangenomen, dat de koper en de verkoper beiden de normale, vereiste bekwaamheid bezitten om de onderneming te kunnen leiden. Een extra grote bekwaamheid verkrijgt trouwens een premie, waardoor de winst daalt, zodat de extra bekwaamheid niet in de waarde van de goodwill begrepen kan zijn.

Waardering van de goodwill betekent in feite niets anders, dan het taxeren van de kans op een extra rentabiliteit, d.i. een rentabiliteit boven de aangelegde subjectieve rentabiliteitseis.

Om de mate van zijn verwachting van een extra rentabiliteit in een getal te kunnen uitdrukken dient het waarderend subject te beschikken over een inzicht in de factoren, welke de winst in het bijzondere geval zullen kunnen beïnvloeden. Dit is zowel nodig voor het stellen van zijn specifieke rentabiliteitseis, als voor het schatten van de toekomstige winst. Deze factoren hebben betrekking op de toekomstige relatieve positie van de onderneming en op de vooruitzichten voor de bedrijfstak. Onderzocht moet worden in welke opzichten de onderneming een voorsprong heeft op de concurrentie. Dit is belangrijk, daar er verschil bestaat in de duur van de voorsprong. De gegevens voor de duurzaamheid der betrekkelijk gunstige positie moeten voor een deel worden ontleend aan een analyserend onderzoek van het verleden. ,In het verleden ligt het heden, in het nu, wat komen zal". Evenwel mag ook niet worden vergeten: „Opgaan, blinken en verzinken”. Het verleden is slechts als een hulpmiddel te beschouwen. Het onderzoek van de voorafgaande jaren heeft tot doel tot vergelijkbare en normale winsten te komen, teneinde de meer duurzame ontwikkelingsfactoren te kunnen opsporen, zowel voor de onderneming als voor de bedrijfstak. Het is daarvoor noodzakelijk de winst te kennen per artikel en per afzetmarkt. Conjuncturele en structurele invloeden dienen zoveel mogelijk te worden onderzocht. Het gaat hierbij niet in de eerste plaats om over een min of meer aangenomen conjunctuurperiode de trend te bepalen. Het gaat om de economische verklaring van de richting van de trend van afzetten, kosten en prijzen. Hiervoor is een inzicht vereist in de ligging van de betreffende onderneming in de bedrijfstak en van de positie van de bedrijfstak ten opzichte van de algemene ontwikkeling. Bij de relatieve positie van de onderneming in de bedrijfstak kunnen onder meer de volgende factoren optreden:

a. De grootte en structuur (Differentiatie, integratie, specialisatie, parallelisatie, normalisatie, typisatie enz.).

b. De verkoop-en distributiepolitiek en -organisatie (o.a. monopolistische concurrentie).

c. De productietechniek en -organisatie (In verband met kosten en kwaliteit).

d. Waardevolle en in beginsel voor overdracht vatbare relaties (Persoonlijke goodwill).

e. De vestigingsplaats (Ook in verband met personeel en grondstoffen).

f. De financiering en het financiële weerstandsvermogen.

g. De public-relations, personeelsverhoudingen e.d.

h. De ouderdom en bekendheid van de onderneming (Traagheidsgoodwill).

i. De administratieve organisatie.

Bij de verhouding van de bedrijfstak ten opzichte van het gehele bedrijfsleven zijn o.a. van belang de aard van de artikelen en afzetmarkten, de mogelijkheid van vervangingsproducten, de conjunctuurgevoeligheid, de afhankelijkheid van de overheidspolitiek, de invloed van de buitenlandse 
concurrentie, de exportmogelijkheden, de veranderingen in de verbruiksgewoonten enz.

Indien een min of meer bevredigende verklaring is gevonden van de ontwikkeling in het verleden tot het heden - hetgeen door de aanwezigheid van vele imponderabilia nimmer objectief kan geschieden, te meer. daar de voor dit onderzoek benodigde kennis van de positie van concurrenten voor een deel zal ontbreken - moet worden overgegaan tot een onderzoek naar de te verwachten toekomstige ontwikkeling van de bovenvermelde invloeden. Dit is een zeer speculatieve aangelegenheid, daar geenszins vaststaat, dat de oorzaken van de gevonden structurele ontwikkeling zullen blijven bestaan. Het is altijd moeilijk te beoordelen, wat de concurrentie van plan is, in hoeverre nieuwe concurrenten kans van slagen zullen hebben en welke veranderingen zullen kunnen optreden in de relatieve positie van de onderneming en van de bedrijfstak. Om hier meer inzicht in te verkrijgen zou onder meer een momentopname van de verschillende markten en van het aandeel van de onderneming in de totale verkoopmarkt nodig zijn. Dit zou ook een vastere basis verschaffen aan de conclusies, welke uit de oorzakenanalyse worden getrokken. Een dergelijke momentopname in de vorm van een marktanalytisch onderzoek (o.a eventueel enquete) is slechts volledig door te voeren, indien zij tevens ten behoeve van andere doeleinden dan goodwillbepaling moet worden toegepast. Men zal zich dus wel voor de goodwillbepaling moeten behelpen met vermoedens op grond van de voorhanden zijnde statistische gegevens.

Zeker is, dat de relatieve positie van de onderneming zal verslechteren. indien niet steeds nieuwe initiatieven worden ontwikkeld. Op grond hiervan kan worden gesteld, dat de duurzaamheid van de op het moment van waardering verwachte extra rentabiliteit beperkt is tot het aantal jaren. hewelk de concurrentie nodig zou hebben om de voorsprong van de betreffende onderneming in te halen, indien geen nieuwe initiatieven zouden worden genomen. Worden deze wel ontwikkeld, dan kunnen zij eventueel tot nieuwe goodwill leiden.

Op deze gedachte is de disconteringsmethode van de ondernemerspremie als waarderingswijze van de goodwill gebaseerd. Hierbij wordt over een betrekkelijk kort aantal jaren de contante waarde van de toekomstige ondernemerspremie bepaald. De ondernemerspremie is het verschil tussen de ondernemerswinst en de voor de bedrijfstak normaal geachte rente over het eigen vermogen. De discontering geschiedt tegen de algement rentevoet, daar bij het schatten van het aantal toekomstige jaren en van het verloop van de ondernemerspremie over dit tijdvak reeds met de toekomstige risico's is rekening gehouden ${ }^{4}$ ).

De betekenis van deze methode is gelegen in de afscheiding van de risico's uit de rentevoet. Hierdoor is een uitvoerige mathematische analyse mogelijk. Het is echter de vraag of deze afsplitsing niet een kunstgreep is. $Z_{i j}$ steunt op de veronderstelling, dat het concurrentiegevaar kan worden gemeten. Weliswaar kan rekening worden gehouden met risicocoëfficiënten, doch dit betekent een inbreuk op deze veronderstelling. De objectiviteit van de goodwillschatting wordt in het algemeen bij deze methode dan ook niet vergroot. Zowel het aantal jaren, als het verloop van de ondernemerspremie zijn niet anders dan op arbitraire wijze vast te stellen. Bovendien zou men ook het aandeel in de ondernemerspremie van elke voorsprongsbron moeten kennen en het verloop van dit aandeel in het voor elke bron afzonderlijk geschatte aantal jaren. In ieder geval zal men aan elke bron

4) Vgl. A. Mey's opstel in het speciale goodwillnummer van de „Naamloze Vennootschap" Juli/Aug. 1942.

m a b blz. 120 
een bepaald gewicht moeten kunnen toekennen, waarna dit verhoudingsgetal dient te worden vermenigvuldigd met het voor iedere bron geschatte aantal jaren. Op deze wijze wordt dan een gewogen-gemiddeld aantal jaren bepaald, waarover de totale ondernemerspremie wordt gedisconteerd. Het is duidelijk, dat hier het subjectieve inzicht een grote rol zal spelen. Slechts bij persoonlijke en traagheidsgoodwill zal deze methode op meer objectieve gegevens berusten, daar in dit geval het toekomstige aantal jaren klein is en over dit aantal jaren practisch slechts één bron van belang is 5 ). Veelal zullen deze soorten goodwill tevens gepaard gaan met een relatief geringe vermogensinvestering, waardoor de rentevoet dus ook geen grote betekenis meer heeft. In dit geval gaat het in de regel voornamelijk om de ondernemerspremie als het verschil tussen het verwachte inkomen en de geëiste arbeidsbeloning voor het leiden van de onderneming, resp. voor het uitoefenen van het vrije beroep.

Het is naar mijn mening echter twijfelachtig of de disconteringsmethode van de ondernemerspremie als opbrengst van vermogen over een geschat, vrij kort aantal jaren, zoals deze door A. Mey is geanalyseerd in het goodwillnummer van de "Naamloze Vennootschap", een juister waarderingsprincipe is, dan de methode, waarbij de subjectief bepaalde extra rentabiliteit wordt gekapitaliseerd als een eeuwigdurende rente. De geanalyseerde onzekerheden worden bij deze methode ineens opgenomen in de rentevoet van kapitalisatie ${ }^{6}$ ). Indien de werkelijkheid met de verwachting overeenkomt, verkrijgt de ondernemer de door hem geëiste beloning voor de ontwikkeling van nieuwe initiatieven, welke nodig zijn om de voorsprong te behouden.

De toekomstige onzekerheden, voortvloeiende uit de positie van de bedrijfstak en de ligging van de onderneming in deze bedrijfstak, hangen onverbrekelijk samen, zodat de aangelegde rentabiliteitseis over het intrinsieke vermogen dezelfde zal zijn als de rentevoet, waartegen de extra rentabiliteit wordt gekapitaliseerd 7 ). De waarde van de goodwill kan dan ook worden geschat door de rentabiliteitswaarde van het eigen vermogen te verminderen met de intrensieke waarde van dit vermogen. De rentabiliteitswaarde wordt gevonden door de verwachte winst - vermeerderd met de kostenfactor rente en verminderd met de in de toekomst te betalen rente van het vreemde vermogen - te kapitaliseren tegen de rentabiliteitseis (Kapitaliseringsmethode). De intrensieke waarde is de totale vervangingswaarde van de voor de uitoefening van het productieproces noodzakelijke activa, verminderd met het vreemde vermogen.

$\mathrm{Bij}$ de waardering van de onderneming kan de liquidatiewaarde nog een rol spelen. Indien namelijk de verwachte rentabiliteit kleiner is dan de ge-

5) Prof. Dr N. J. Polak, „Vooruitzicht en Terugblik” in de "Naamloze Vennootschap" van October 1947, geeft hierover interessante berekeningen. Zie ook G. Andriesse, „Naamloze Vennootschap". Februari 1948 - „Berekeningen bij goodwill”.

6) Deze rentevoet zal dus vrij hoog kunnen $z i j n$. Bij een hoge rentevoet is de contante waarde van de in de meer verre toekomst optredende winsten klein, zodat practisch over een beperkt aantal jaren wordt gekapitaliseerd. Bij een rentevoet van bijv. $10 \%$ is de contante waarde van een annuiteit over 20 jaar circa 85 procent van de contante waarde van deze annuiteit over 100 jaar. Vgl. P. D. Leake „Commercial goodwill".

7) In deze uitlating kan een critiek worden gezien op de bekende methode van Schmalenbach, waarbij de goodwill wordt geschat als een getal, gelegen tussen de rentabiliteits- en intrensieke waarde. Hetzelfde resultaat wordt ook verkregen, indien de extra rentabiliteit tegen een hogere rentevoet dan de over het intrensieke vermogen geëiste rentabiliteit wordt gekapitaliseerd. Bij deze methoden wordt de bedreiging van de voorsprong van de onderneming niet in deze rentevoet verdisconteerd, zodat het concurrentiegevaar op een andere wijze tot uitdrukking moet worden gebracht.

m a b blz. 121 
eiste zal practisch op basis van de liquidatiewaarde moeten worden gewaardeerd. Dit behoeft geen stellige verwachting te zijn. Ook wanneer het waarderend subject de kans op het behalen van de verlangde rentabiliteit even groot acht als de kans op een kleinere rentabiliteit zal hij de liquidatiewaarde moeten aanhouden. Waardering op basis van de intrensieke waarde zal slechts plaats mogen vinden, indien de verwachte winst gelijk is aan de door het waarderend subject geëiste winst, respectievelijk de kans op het behalen van een grotere winst niet aanwezig wordt geacht.

In „Een kwart eeuw V.A.G.A." wijst Drs J. Vogel eveneens op de imponderabilia bij het schatten van de waarde van de goodwill. Indien voor bepaalde bedrijfssoorten een min of meer bepaalde vermenigvuldigingsfactor ter bepaling van de goodwill wordt gebruikt, kan deze volgens Vogel met vrucht worden gehanteerd. De prijs van de goodwill in het specifieke geval wordt dan afgeleid uit de goodwillprijs in de betreffende bedrijfstak. Het voordeel volgens Vogel van deze methode kan zijn, dat in de goodwill prijs - vooral bij een betrekkelijk grote frequentie van overdrachten van soortgelijke ondernemingen - de subjectieve schattingen van een groot aantal personen tot uitdrukking komen. Door Hogeweg wordt er op gewezen, dat bij deze methode geen voldoende rekening wordt gehouden met de individuele verschillen tussen de ondernemingen ${ }^{8}$ ). Hogeweg blijkt een voorstander te zijn van de reeds eerder besproken kapitaliseringsmethode. In de literatuur over het goodwillvraagstuk wordt ook steeds gewezen op de omstandigheid, dat er geen bepaalde marktfactor is, maar dat deze varieert tussen twee vrij ver uit elkaar liggende getallen ${ }^{9}$ ). Het komt mij voor, dat dit in de practijk inderdaad veelal het geval zal zijn, onder meer als een gevolg van het verschil in relatieve positie der ondernemingen in de betreffende branche. Dit verschil in positie komt niet alleen tot uitdrukking in de afwijkende grootte van het basisgegeven, waarop de marktfactor wordt toegepast, maar ook in de grootte van deze factor zelf. De meerdere of mindere duurzaamheid van de voorsprong is hierbij van belang. Bij de vermenigvuldigingsmethode wordt de specifieke factor als een getal tussen de beide uitersten van de marktfactor geschat op grond van een analyse van de voorsprong. Deze analyse moet de basis geven voor de intuitie, waarmee het waarderend subject de relatieve positie van de te waarderen onderneming in de bedrijfstak bepaalt.

Naar mijn mening heeft de methode van de marktfactor betekenis als een methode naast de kapitaliseringsmethode, eventueel disconteringsmethode. De volgens een der laatste methoden geschatte goodwillwaarde wordt via het basisgegeven (de winst, de overwinst, de omzet e.d.) herleid tot de specifieke marktfactor. De ligging van dit getal ten opzichte van de uitersten van de marktfactoren moet dan worden beoordeeld in verband met de positie van de onderneming in de bedrijfstak. Bij een belangrijke afwijking is dan de conclusie, dat er een differentie is tussen de subjectieve waarde van de goodwill en de uit de marktprijs van de goodwill afgeleide goodwillprijs in het specifieke geval.

Op de betaalde goodwill zal uit veiligheidsoverwegingen worden afgeschreven. In de conceptie van de disconteringsmethode der ondernemerspremie moet ook worden afgeschreven, daar hier de goodwillprijs voorstelt de contante waarde van een tijdelijke rente. Bij de kapitaliseringsconceptie betekent het afschrijven op de betaalde goodwill het vormen van een geheime reserve, zolang de werkelijkheid overeenstemt met de verwachting.

8) G. P. J. Hogeweg in de bespreking van de jubileumbundel 25-jarig bestaan V.A.G.A. in het Mab, October 1952.

9) Vgl. o.a. H. Kaner ,A new theory of goodwill”.

m a b blz. 122 
Immers in dat geval ontvangt de ondernemer de verlangde winst, welke de grondslag vormde voor de prijs van de onderneming, zodat de uitkering van deze winst principieel mag plaats vinden.

\section{Accountant en verantwoordelijkheid}

Het is gewenst voorafgaande aan het vraagstuk ..Accountant en goodwill' de visie te geven op de verantwoordelijkheid van de accountant in de controlerende functie.

Te onderscheiden zijn de zedelijke en de vaktechnische verantwoordelijkheid. De zedelijke verantwoordelijkheid heeft betrekking op het al of niet aanvaarden van opdrachten als vakman. Daar de accountant een economische functie vervult, bestaat deze verantwoordelijkheid uit het afwegen van het nut van de contrôle in verband met de daarmede samenhan gende kosten. De vaktechnische verantwoordelijkheid betreft de werkwijze welke bij de verschillende doelstellingen van de contrôle moet worden gevolgd. In het kort gezegd betreft de zedelijke verantwoordelijkheid dus het "of" en de vaktechnische het ",hoe".

In het bijzonder bij de jaarrekeningcontrôle kunnen dan nog verschillende modellen worden onderscheiden op grond van de mate van de door eigen actie bereikbare zekerheid ${ }^{10}$ ). Bij elk model dient te worden uitgegaan van minimum eisen, waaraan organisatie en administratie moeten voldoen, rekening houdende met de doelstelling, welke kan zijn contrôle ten behoeve van het maatschappelijk verkeer of contrōle ten behoeve van de bedrijfsleiding. Mocht voor de bedrijfsleiding wel een opdracht aanvaardbaar zijn en voor het maatschappelijk verkeer niet, dan dient in de verklaring deze doelstelling tot uitdrukking te komen, teneinde het certificaat voor derden waardeloos te maken. De minimum eisen hebben de betekenis van een grens, waar beneden contrōle zinloos moet worden geacht.

Voor de vaktechnische verantwoordelijkheid heeft de vertrouwenstheorie normen bepaald. De essentie van deze theorie is, dat de uit elke doelstelling voortvloeiende eisen voor 100 procent moeten worden vervuld door middel van de vaktechniek. De contrôle, welke dan ontstaat, wordt een volkomen contrôle genoemd. Voor de jaarrekeningcontrôle betekent dit, dat 100 procent contrōletechnisch bereikbare zekerheid moet worden gegeven, gezien de functie van de jaarrekening als de verantwoording van het beheer 11).

De veronderstelling, waarvan de vertrouwenstheorie uitgaat is, dat de bij elke doelstelling en model gevraagde zekerheid tenminste gelijk is aan de zekerheid, welke de volkomen contrôle kan geven. Verondersteld wordt dus, dat het nut van de volkomen contrôle tenminste gelijk is aan de kosten van deze contrôle. De contrôlekosten kunnen dus geen rol spelen. Dit is het axioma van de vertrouwenstheorie. Men vindt deze veronderstelling ook bij het leerstuk van de functionele plaats der contrôle van de organisatietheorie van Prof. Limperg. Dit axioma is ontleend aan het begrip zekerheid. Zekerheid is evenals de waarheid een absoluut begrip. Het staat van te voren vast, dat de accountant zelfs in het meest ideale geval slechts een surrogaat van de absolute zekerheid kan leveren. Dit surrogaat is ",kosteloos".

Het is duidelijk, dat door deze veronderstelling het probleem der zede-

10) Vgl. P. J. H. J. Bos, Prae-advies Accountantsdag 9 October 1954.

11) Voor het begrip 100 procent contröletechnisch bereikbare zekerheid verwijs ik naar het artikel van Prof. A. M. van Rietschoten in het Mab. Juni 1954.

m a b blz. 123 
lijke verantwoordelijkheid in principe wordt opgelost. Slechts die opdrachten kunnen niet worden aanvaard, waarbij niet voldaan wordt aan de minimum eisen, welke, gezien de doelstelling en het model, gesteld dienen te worden.

De minimum eisen zijn voor subjectieve interpretatie vatbaar. Hierop wordt in het onderstaande nog teruggekomen. Wordt wel aan deze eisen voldaan, dan is niet alleen aanvaarding van de opdracht geoorloofd, maar deze moet ook worden anvaard. Het zich onttrekken aan vaktechnisch te dragen verantwoordelijkheid is voor de vakman even onzedelijk als het te lichtvaardig op zich nemen van verantwoordelijkheid. Men denke aan de chirurg, die zich technisch in staat acht een moeilijke operatie te volbrengen, welke voor het leven van de patiënt van groot belang is, maar die de opdracht niet aanvaardt, omdat zij kan mislukken. Voor de patiënt hebben de kosten van de operatie in dit geval geen betekenis en zo is het ook bij de contrôle volgens het axioma van de vertrouwenstheorie.

In de economische werkelijkheid hebben de kosten echter wel betekenis. Dit vloeit voort uit de relativiteit van de psychologische behoefte aan zekerheid. Vandaar dat bij de toepassing van de vertrouwenstheorie door de accountants spanningen optreden, welke men tracht weg te nemen door een subjectieve inhoud aan de vertrouwenstheorie te geven. Dit betekent een afstand doen van de veronderstelling van deze theorie.

Wanneer b.v. bij een ziekenfonds het grote aantal uitgaven, waarvan elke post een relatief gering belang vertegenwoordigt, door middel van steekproeven wordt gecontroleerd, dan is dit strijdig met het axioma. Men kan beredeneren, dat gezien het relatief kleine belang van elke post, de bekendheid van het totale bedrag en de spreiding in de bedragen, steekproeven contrōletechnisch geoorloofd zijn, doch dan gaat het niet meer om de 100 procent bereikbare zekerheid, maar om de naar eigen inzicht 100 procent te bereiken zekerheid. De beslissing om steekproeven toe te passen als vervanging van een integrale detailcontrôle is dus een subjectieve beslissing. Is dit besluit eenmaal genomen, dan dient met behulp van de steekproeftheorie de bepaling van de omvang van de steekproef in het objectieve vlak te worden gebracht. Wil men bij een handelszaak of industrieel bedrijf steekproeven toepassen ter vervanging van de integrale detailcontrôle. dan dient men zich te realiseren, dat dit een subjectieve beslissing van grotere betekenis is, dan bij het ziekenfonds (of pensioenfonds enz.). Deze detailcontrôle is immers bij dit soort ondernemingen ook van belang voor het verkrijgen van meerdere zekerheid omtrent de verkopen (Vlg. Prof. A. M. van Rietschoten in Mab Juni 1954).

Er is nog een andere grond voor het subjectieve inzicht in de toe te passen vaktechniek. Naarmate namelijk het verifiërende karakter van deze techniek afneemt, neemt het subjectieve inzicht in betekenis toe. Dit is dus het geval bij een investigation vergeleken met de jaarrekeningcontrôle, doch dit doet zich ook voor naarmate bij de jaarrekeningcontrôle de bereikbare zekerheid afneemt. Bij de contrôle van een algemene bank is het individuele inzicht in de toe te passen vaktechniek van meer betekenis dan bij de contrôle van een normale handelszaak, daar bij de algemene bank de interne contrôle een relatief grotere betekenis heeft in verhouding tot de bereikbare eigen actie. De beoordeling van de betekenis van deze interne contrôle in verband met de uit een oogpunt van verbijzonderde contrôle te stellen minimumvoorwaarden stelt hoge eisen aan het inzicht van de accountant en zal meer verschil van mening kunnen doen ontstaan dan bij de handelszaak. Daar bij de controlerende functie ten behoeve van de bedrijfsleiding de grens, waar beneden contrôle geen zin heeft, op een lager

m a b blz. 124 
niveau ligt, dan bij de accountantscontrôle ten bate van het maatschappelijk verkeer zullen deze meningsverschillen in het bijzonder in het laatste geval aan de dag treden.

Tenslotte doet in concrete gevallen het subjectieve inzicht zich gelden bij de vraag of de jaarrekening in verband met de waardering en resultatensplitsing, resp. resultatenomschrijving een juist beeld vertoont.

Het bovenstaande betekent dus, dat de vertrouwenstheorie grenzen heeft en dat de uit de specifieke functie voortvloeiende normen niet altijd objectief kunnen worden bepaald 12). In dit licht beschouwd kan m.i. de uitspraak van Prof. Dr A. Mey, dat er geen tegenstelling kan bestaan tussen theorie en practijk, aanleiding geven tot misverstand. (Voorwoord tot de Encyclopaedie der Accountantscontrōle). Er is een derde mogelijkheid, namelijk dat door de begrensdheid van de theorie niet kan worden aangegeven, welke van beide onjuist is.

Ook de verantwoordelijkheid voor de contrôle ter voorbereiding van het goodwilladvies is niet objectief te begrenzen. Bij dit onderzoek is elke opdracht een model, zodat pas tijdens de contrōle de minimum voorwaarden voor de benodigde tijd en de administratie blijken. Daar van de accountant, evenals van iedere vakman, niet meer dan het bereikbare wordt verwacht, $z$ al hij niet te spoedig te kennen moeten geven, dat hij geen oordeel heeft, indien de administratie relatief weinig gegevens verschaft. Aan het inzicht van de accountant worden dus hoge eisen gesteld en het bedrijfseconomisch oordeel zal subjectief-deskundig worden bepaald.

Het vraagstuk van de goodwillwaardering ligt in een geheel ander vlak. Op dit probleem zal hieronder nader worden ingegaan.

\section{Accountant en goodwillwaardering.}

Reeds in de controlerende functie is de accountant genoodzaakt het verband na te gaan tussen de verstrekte cijfers en de omstandigheden van economische en technische aard, waaronder de onderneming heeft gewerkt. Hiertoe behoort dus ook de beslissing over het aantal jaren dat in de cijferbeoordeling zal worden betrokken, het elimineren van bijzondere winsten en verliezen - ook speculatieresultaten - het adjusteren van afschrijvings- en onderhoudsrekeningen, het onderzoek van de weerspiegeling van structurele en conjuncturele invloeden op omzetten, prijzen, bezetting en kosten en het nagaan of reeds bepaalde feiten zijn ingetreden of zijn te verwachten, welke het resultaat zullen beïnvloeden, zoals de afloop van alleen-vertegenwoordigings, huur- en personeelscontracten, wijzigingen in de productiemethode e.d.

De adviserende functie is gericht op het bepalen van een waarde. In meer gecompliceerde gevallen zal voor de uitoefening van deze functie een gedetailleerder inzicht nodig zijn, dan noodzakelijk is voor de contrôle van de betrouwbaarheid der gegevens. Een overzicht van en een inzicht in mogelijke toekomstige veranderingen in de positie van de bedrijfstak en in de positie van de onderneming is vereist. Juist in de meer ingewikkelde. gevallen zal de accountant veelal in dit opzicht een geringere kennis bezitten dan de ondernemer, zodat uit vaktechnische overwegingen de beoordeling van de toekomst en de daarmede onverbrekelijk samenhangende. waardebepaling van de goodwill aan deze zou moeten worden overgelaten. Een gebrek aan kennis kan echter worden aangevuld. Indien partijen van de accountant een advies verlangen, zullen zij voor deze aanvulling kunnen

12) Zie voor een andere opvatting P. J. H. J. Bos, Prae-advies Accountantsdag 9 October 1954

$\mathrm{m}$ a b blz. 125 
zorg dragen. Hiertegen is op zich zelf geen bezwaar, tenzij het hiaat in specifieke kennis zodanig is, dat het gevaar van eenzijdige beinvloeding van de accountant virulent wordt. Er is evenwel nog een bezwaar verbonden aan de waardering van de goodwill voor de accountant. Dit is de subjectieve verwerking van het toekomstbeeld en de subjectieve vaststelling van de rentabiliteitseis, respectievelijk bij de disconteringsmethode de sub. jectieve bepaling van het aantal jaren, waarover de ondernemerspremie zal worden berekend en van het verloop van de ondernemerspremie in deze jaren. Bij de marktwaardemethode komt dit karakter naar voren bij de schatting van de specifieke vermenigvuldigingsfactor. Deze factoren dienen te worden geschat door de ondernemende partijen. De verantwoordelijkheid voor de uitkomst kan in principe niet aan een derde worden gedelegeerd. Voor de accountant betekent dit, dat hij bij de waardering van de goodwill een verantwoordelijkheid op zich neemt, die hij niet als vakman kan dragen. In wezen geeft de accountant een partijdig oordeel, namelijk een oordeel gegrond op intuitie en niet op wetenschappelijk inzicht. Dit is het principiële verschil met controlerende en meer objectief adviserende functies, zoals kostprijscalculaties e.d. 13)

Volgt uit het voorgaande, dat dus de accountant zich uitsluitend moet bepalen tot de controlerende functie bij een goodwillopdracht? Het antwoord hangt af van de beantwoording van twee andere vragen:

le. Verwacht het maatschappelijk verkeer van de accountant een specifiek subjectief oordeel in de adviserende functie bij de goodwillbepaling.

2e. Zo ja, wordt door het voldoen aan het verlangen van partijen de controlerende functie, d.i. de hoofdfunctie van de accountant, benadeeld. respectievelijk wordt door het afwijzen van de opdrachten tot waardebepaling deze functie versterkt.

Naar mijn overtuiging wordt van de accountant inderdaad een schattingsoordeel verwacht. Het feit, dat veelal iedere partij een deskundige benoemt, wijst hier m.i. op. Anderzijds rust op de accountant de plicht aan de opdrachtgever(s) duidelijk te maken, dat hij niet als accountant optreedt, doch als een bedrijfseconomisch-geschoolde ondernemer, respecievelijk als een ,goodwillmarkt" -deskundige.

Indien partijen in volle vrijheid onderhandelen, kunnen zij uiteraard van het advies afwijken. Bij een bindend advies is dit niet mogelijk. Hier rijst de vraag of de subjectieve schatting van de accountant, respectievelijk het resultaat van de subjectieve oordelen der betrokken deskundigen, in het bijzonder voor de verkoper van de onderneming geen nadelen inhoudt. Accountants zijn in het algemeen voorzichtig, zodat in het waardeadvies. de waardering van een behoedzaam ondernemer tot uitdrukking zal komen. Het is niet uitgesloten, dat de verkoper en koper meer risicominded zijn. In dit geval zou bij vrije onderhandelingen wellicht een hogere prijs zijn tot stand gekomen. Het maatschappelijk verkeer is echter wel op de hoogte van de neiging der deskundigen de goodwill aan de voorzichtige kant te

13) Dit betekent allerminst, dat in deze gevallen bij de toepassing van de (bedrijfs-) economie de grens tussen deze wetenschap en de intuïtie scherp is af te bakenen. Vgl. Prof. Dr B. Pruyt in De Economist Nov. ' 54 en Prof. Dr J. L. Mey in het Mab. Nov. '54.

Ook met betrekking tot de aan de administratie en interne controle te stellen minimum eisen, alsmede betreffende de omvang en duur van de accountantscontrole zelf — als een labiel organisatorisch evenwicht tussen het functionele criterium der vertrouwenstheorie en het kostencriterium volgens de theorie der quantitatieve verhoudingen — speelt het subjectieve beleidselement van de organisatie der accountants bij de beinvloeding van de contrôleconventies en de subjectieve interpretatie door de individuele accountant van deze conventies, zoals reeds werd uiteengezet, een rol van betekenis.

m a b blz. 126 
schatten. Ook de verkoper, welke zich bereid heeft verklaard het bindend advies te aanvaarden, was hiermede bekend.

Er blijft nog over de vraag, welke invloed het aanvaarden van opdrach ten tot waardeschatting van de goodwill heeft of kan hebben op de verwachting van het maatschappelijk verkeer ten aanzien van de objectiviteit van het oordeel van de accountant in de algemeen controlerende functie. Men zou van mening kunnen zijn, dat het stelselmatig weigeren van deze waardeadviezen de verwachting van het verkeer met betrekking tot de controlerende functie op een hoger niveau zou brengen, dan reeds het geval is. Uiteindelijk zou dit dan zowel in het belang van het maatschappelijk verkeer als van de accountantsstand zijn. Naar mijn oordeel dient men echter nimmer uit het oog te verliezen, dat het maatschappelijk verkeer nu eenmaal de behoefte heeft aan goodwilladviezen door onafhankelijke bedrijfseconomisch geschoolde deskundigen, hetzij door een gebrek aan economisch inzicht, hetzij door de behoefte aan een arbiter. Van deze des kundigen is de accountant de meest aangewezen persoon, daar hij door zijn contrôledeskundigheid tevens in staat is een gefundeerde interpretatie te geven van de in het verleden behaalde resultaten, zoals deze uit de overgelegde gegevens blijken. Een op contrôle gebaseerde interpretatie is zeer belangrijk, daar de toekomstverwachtingen mede op basis van het verleden worden opgebouwd. Hieruit volgt, dat de schatting van de waarde van de goodwill als advies niet los is te maken van de controlerende functie, waarbij deze functie dan in zijn bedrijfseconomische betekenis moet worden opgevat.

Indien de goodwill moet worden bepaald in een fiscale of juridische figuur, waarbij een feitelijke overdracht in de vorm van onderhandelingen tussen partijen niet plaats vindt, zal de accountant nog rekening moeten houden met eventuele fiscale of juridische jurisprudentie, voorzover deze van belang kan zijn voor de waardering.

De voorafgaande beschouwing leidt tot de gevolgtrekking, dat opdrachten tot goodwillwaardering door de accountant in het algemeen kunnen worden geaccepteerd, een conclusie, welke in overeenstemming is met de gevolgde practijk.

Tenslotte wil ik nog opmerken, dat in het bovenstaande betoog slechts een poging moet worden gezien tot het schetsen van de betekenis van de fundamentele onzekerheid van het ondernemen voor de waardering van de goodwill en voor het optreden van de accountant hierbij. De in sommige theorieën en ook in de practijk voorkomende tendenz tot onderschatting van deze betekenis vormde de aanleiding tot deze beschouwing. 